\title{
巨核球の分化
}

寮 隆 吉*, 足 立 昌 司*, 西 郷 勝 康*

\section{Regulation of Megakaryocytopoiesis}

\author{
Ryukichi RYO*, Masashi ADACHI*, Katsuyasu SAIGO*
}

Key words : CFU-Meg, IL-3, IL-6, ploidy, GPIIb/IIIa

\section{はじめに}

巨核球は分化して血小板を産生するが，分化 過程とその制御機構について不明な点が多い. 巨核球が骨髄細胞の中で占める割合が低く，巨 核球を用いる実験が手軽におこなえなかったか らである。しかし 1960 年初頭からげっ歯類の 巨核球分化に関する研究がはじまり現在までに 数多くの知見が集積された。これは人の巨核球 の同定方法がなかったのに反してげっ歯類の巨 核球はアセチルコリンエステラーゼ活性の発現 から容易に同定できたので動態を詳しく観察で きたことによる. 近年人の巨核球の分化の過程 も次々に明らかになってきた。これは Vainchenker ${ }^{1)}$ らによって人巨核球コロニー (CFU-Meg) 形成法が確立され in vitro で各 成熟段階の巨核球を一個一個捉えることができ るようになったことと巨核球が血小板ペルオキ シダーゼ (PPO) 活性や血小板特異蛋白である 膜糖蛋白（GP） などのモノクローナル抗体を 使って容易に同定 ${ }^{2)}$ できるようになったこと による．また造血細胞を制御するサイトカイン の多くがクローニングされリコンビナントのサ イトカインが手に入るようになったこども 巨核球分化の制御機構の解明に役立っている. 今回は (1) 巨核球分化の研究のための巨核球の 取り扱い方法，(2) 巨核球分化を司るサイトカ イン，(3) 巨核球の分化過程について興味ある
話題を解説したい.

なお巨核球分化の総説は今までに多くの業績 を挙げてこられた先生方によって書かれた血小 板 1989-血小板産生-4) と, Hoffman の書いた “Regulation of megakaryocytopoiesis"5) があ り参照していただきたい.

\section{巨核球の取り扱い方}

\section{（1）CFU-Meg 形成法}

骨髄細胞の単核細胞を血漿凝血法1), メチル セルロース法6)，フィブリン凝血法7) あるいは 軟寒天法8) などによって培養すると巨核球コ ロニーを得ることができる. Kimura ら ${ }^{6)}$ はメ チルセルロース法が巨核球の形態をよく保つと しているがいずれの方法も有用である. 近年各 種サイトカインの影響をみるため, 生理的に存 在するサイトカインを含む血清を使わず，さら にサイトカインを出す可能性のある付着細胞や $\mathrm{T}$ 細胞を除いた単核球からの巨核球コロニー 形成をみる方法がよいとされている819). その 一つである Teramura らの方法を表1に示す。 cloning efficiency は血漿を使った場合に比較 して 60〜 70\% と低值で，各コロニーサイズは 小さいが，十分分化過程を観察できるという。 progenitor は通常骨髄細胞からの単核球を用 いるが，正常骨髄細胞をいつも手に入れるのは 容易ではない. Mazur ら ${ }^{10) 11)}$ は常に末梢血由 来の単核球を用いて CFU-Meg を作成し IL-3

* 神戸大学医学部付属病院輸血部〔テ 650 神戸市中央区楠町 7-5-2〕; Blood Transfusion Service, Kobe University Hospital 7-5-2 Kusunoki, Chuo-ku, Kobe, Hyogo Japan 650 
表 1 巨核球コロニー無血清培養法

\section{〔方 法]}

\section{ヒト巨核球コロニー 無血清培養法}

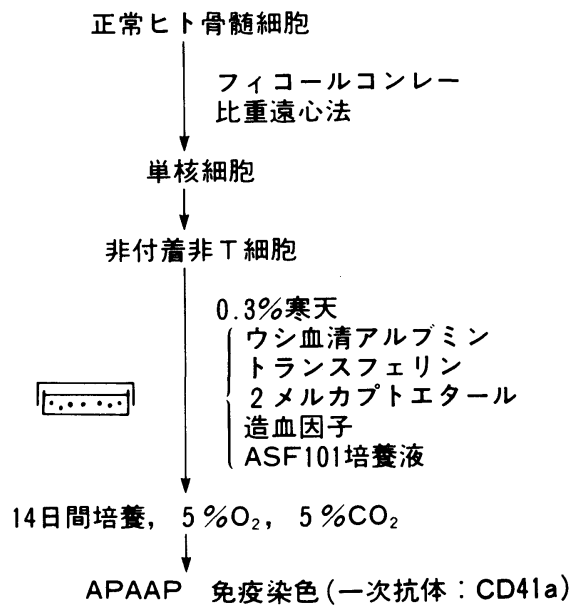

や GM-CSF に対する反応を検討しているが， 骨髄細胞由来の単核球からの CFU-Meg の反 応とほぼ同一の成績を得ている。骨髄細胞の入 手の困難な場合は試みてよいであろう。ただ末 梢血中の幹細胞は骨髄細胞中のそれよりやや成 熟した段階にあるといわれているので，その点 を考慮しつつデータの解析をおこなう必要があ るかもしれない. CFU-Meg の成績としては, コロニー数やコロニー中の巨核球数から巨核球 progenitor の増殖能をそして形成された巨核 球の ploidy，抗原発現量そして size の大きさ から分化能を判定するのが一般的である。これ らを指標として巨核球コロニーはコロニー形成 に時間がかかるが一個コロニー当たりの巨核球 数が 30 個以上と多い BFU-Meg ${ }^{16) 12)}$ と一般的 に得られる CFU-Megの 2 つの population か ら成っていることが明らかにされており，赤血 球コロニーが BFU-E と CFU-E から成ってい るのとほぼ同様である。

\section{(2) 巨核球の分離}

巨核球の比重や size の特徵を利用したり, 巨核球 lineage に特異的な GPIIb/IIIa に対す
表 2 巨核球分離

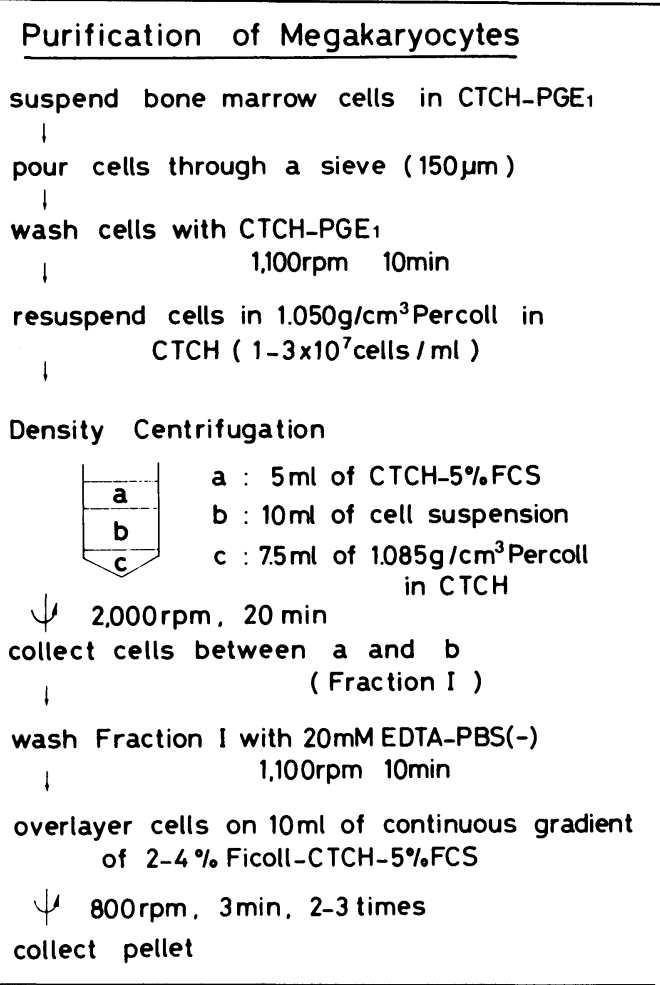

るモノクローナル抗体を使って骨髄細胞から濃 縮分離することができる，生理的な状態に近い 巨核球の確保と言えるかもしれない.

density centrifugation と velocity sedimentation の組み合わせ

巨核球は $1.022 〜 1.089$ の間の比重を有して いるのでアルブミン非連続勾配（1.035～1.050 $\mathrm{g} / \mathrm{cmm})^{13)}$ そして Percoll (1.016〜1.078 g/ $\mathrm{cmm})^{14)}$ などが分離，濃縮に用いられる．Percoll は巨核球膜の透過性に対する抵抗性が消失 した後も細胞内に侵入しないので一番適してい るかもしれない. 比重の違いで濃縮した後 $1 \mathrm{G}$ から $1500 \mathrm{G}$ の遠心を負荷して純度を上げるこ とができる，なお巨核球は容易に凝集するので 凝集阻害剤であるアデノシン，テオフィリン， prostaglandin $\mathrm{E}_{1}\left(\mathrm{PGE}_{1}\right)$ の使用そして分離液 からの $\mathrm{Ca}^{2+}$ や $\mathrm{Mg}^{2+}$ の除去などの工夫が行 われている．Fedorkoら ${ }^{13)}$ の方法を改変した われわれの方法を表 2 に示す。また counter flow centrifugation といって遠心力と遠心と 


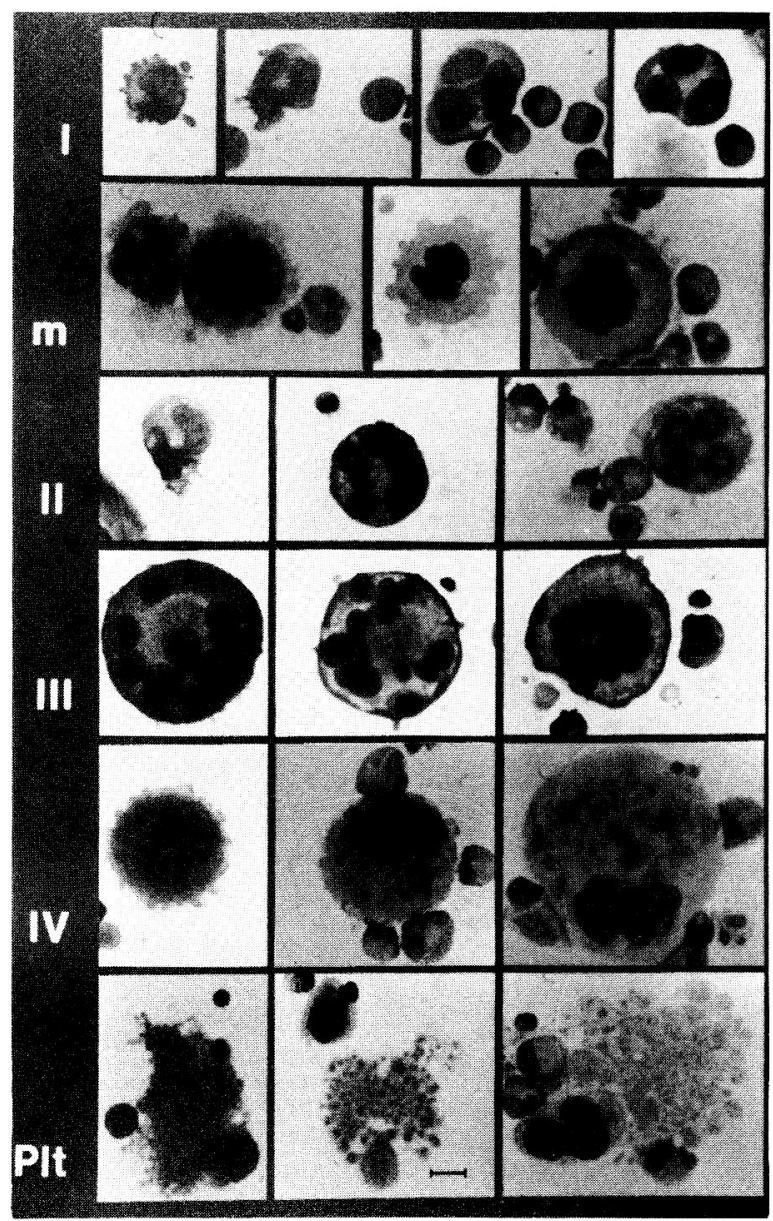

図 1 cell elutriator による巨核球の分離．文献（8）より

は逆方向の流水力を負荷できるよう設計された cell elutriator を使うと沈降速度に応じた巨核 球が採取できる ${ }^{16) 17)}$. Straneva らは骨䯣細胞 から Ficoll-Hypaque で単核球を分離した後, cell elutriator に負荷して progenitor から血 小板産生を示寸巨核球を分離した ${ }^{18)}$ (図 1). 各 成熟段階の巨核球に対するサイトカインの影響 や, 血小板産生過程の形態学的特徵の検討が可 能である。

\section{免疫学的手法による分離}

Tomer ら ${ }^{19)}$ は Percoll で $1.050 \mathrm{~g} / \mathrm{cmm}$ 以 下の骨䯣細胞を採取した後, GPIIb/IIIa モノ クローナル抗体を用いて fluorescence activated cell sorting cell sorter で行い $98 \%$ の純 度の巨核球を分離，短期培養に成功した。この 方法は GPIIb/IIIa 発現のない巨核球 progenitor は捕捉できないので CFU-Meg を形成する
細胞分画には有効でない.

\section{（3）巨核芽球性白血病細胞株}

血球分化の研究に in vitro で短い doubling time を持って增殖する白血病細胞株が良く用 いられるが多くの巨核芽球性白血病細胞株も樹 立されている。表面形質や PPO 発現からどの 成熟段階の腫瘍化由来の細胞株であるかを知っ ておくことが大切である. myeloid, erythroid そして megakaryocytic な phenotype を示し $\mathrm{PPO}$ 活性のない $\mathrm{K} 562^{20)}$ や $\mathrm{HEL}^{21)}$ などの幹 細胞レベルの細胞株, myeloidや erythroidの どちらかのマーカーと megakaryocytic な phenotype を持ち PPO 活性が認められる $\mathrm{CMK}^{22)}, \mathrm{M}-07^{23)}$, Dami cell ${ }^{24)}$ の細胞株, megakaryocytic なマーカーだけを示し血小板 産生を思わせる形態学的特徵を示す Meg$01^{25)}$, EST-1 U ${ }^{26)}, \mathrm{T}-33^{27)}$ などの細胞株はいず 
れも分化に対応した表面形質の変化，遺伝子発 現そして分化の際の signal 伝達機構の研究に 有用である。ただこれらの細胞株は分化する正 常細胞と違って増殖能だけが優位であるという 腫瘍性の特徵があり，分化しても正常な機序の もとでの分化とは考えられない点もあろう。ま た白血病細胞は lineage infidelity があって正 常とは異なった形質発現をすることがあるので 注意したい.

\section{（4） その他}

巨核球の血小板産生能や分化の in vivo の過 程は末梢血小板や size の動きで検討したり， 骨髄細胞中の巨核球の ploidy の変化や CFU. Meg 形成能から観察するが28)，ここでは古く から用いられ今でもマウスなどの血小板産生能 の検索に用いられている ${ }^{75} \mathrm{Se}$-selenomethionine ${ }^{28)}$ p $\mathrm{Na}_{2}{ }^{35} \mathrm{SO}_{4}{ }^{29)}$ 投与後の末梢血中への 標識血小板の出現の程度を用いる方法を紹介し ておきたい.これらの核種は巨核球の胞体に取 り込まれ巨核球の血小板産生に従い標識血小板 が末梢血に出現してくるので末梢の放射活性の 推移を測定することによって巨核球の分化能が 推定できる. 血小板数の変化を追跡するより鋭 敏な方法としてエリトロポエチンの血小板産生 能に及ぼす効果の判定に用いられる29).

\section{巨核球分化を司るサイトカイン}

巨核球数の減少した再生不良性貧血患者の血 清や尿中に巨核球コロニー形成を促進する humoral factor の出現がみられるし ${ }^{30331)}$, in vitro の巨核球コロニー形成のためには PHALCM, WEHI-3 CM あるいは PWM-SCM な どから得られる液性の刺激因子を加える必要が あること5）などから，巨核球分化がサイトカ インによって制御されていることをうかがい知 ることができる．巨核球分化を制御するサイト カインは巨核球 progenitor の増殖に作用する 巨核球コロニー刺激因子（Meg-CSF）と巨核 球の胞体の成熟を促す巨核球分化促進因子 (Meg-potentiator) の 2 つから成っていること が Williams ら ${ }^{32)} に よ っ て$ 明らかにされた。 彼らは巨核球分化を強く促進するマウス myelomonocytic leukemia cell line $の$ condi- tioned medium（WEHI-3 CM）をゲルろ過し 分子量の違う peak に Meg-CSF 活性と Megpotentiator 活性を得て巨核球分化は作用部位

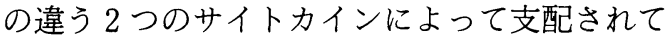
いることを示し，この考えは現在も支持されて いる.

\section{Meg-CSF}

人の Meg-CSF は巨核球の減少した患者の 尿から分離精製が試みられているが現在もなお アミノ酸配列を決定できる程精製できたとの報

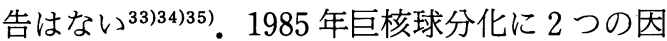
子が必要であることを明らかにした Williams らは WEHI-3 CM 中の Meg-CSF 活性は IL-3 であることを報告した ${ }^{36)}$. 本来 helper $\mathrm{T}$ 細胞 が出す IL-3 を myelomonocytic leukemia cell が恒常的に出すのは IL-3 遺伝子上流にレトロ ウィルス様配列が挿入されていることによる。 同じころ Quesenberry ら ${ }^{37)} も$ IL-3 と GMCSF が巨核球コロニー刺激因子であることを 報告し，従来粗製品の Meg-CSF でおこなわ れていた分化の研究が単一に精製されたサイト カインを使って行われるようになった. IL-3 と GM-CSF はいずれも巨核球 progenitor の cloning efficiency を高めるが, IL-3 の方が作 用は強力である ${ }^{38) 39}$. IL-3 と GM-CSF は相 乗的な作用があり一部異なった機序を介する巨 核球 progenitor 効果があるとされる ${ }^{4014142 \text { ). }}$. Teramura ら ${ }^{43)}$ はアッセイ系に混入してくる サイトカインを排除するため巨核球コロニー無 血清培養法を用いて IL-3 と GM-CSF の影響 を検討し図 2 に示す成績を得た. $10 \mathrm{U} / \mathrm{m} l$ ある いは $50 \mathrm{U} / \mathrm{m} l$ の至適濃度以下の IL-3 と GM-CSF を添加すると相乗効果が認められる が， $100 \mathrm{U} / \mathrm{m} l$ の濃度の IL-3 下では GM-CSF の効果がなかったという. Bruno ら ${ }^{44)}$ は IL-3 と GM-CSF いずれの濃度でも相加効果がある としている. IL-3 と GM-CSF が単独あるい は両者を介して巨核球 progenitor の増殖因子 として働いているのであろう， $\mathrm{Lu}{ }^{38)}$ p Bruno ら ${ }^{44)}$ は各種のサイトカインの効果を検 討し, IL-1 $\alpha$, G-CSF, M-CSF, トロンボポエチ ン刺激因子 (TSF), Epo そして IL-4 は単独 では巨核球コロニー刺激作用がないことを報告 


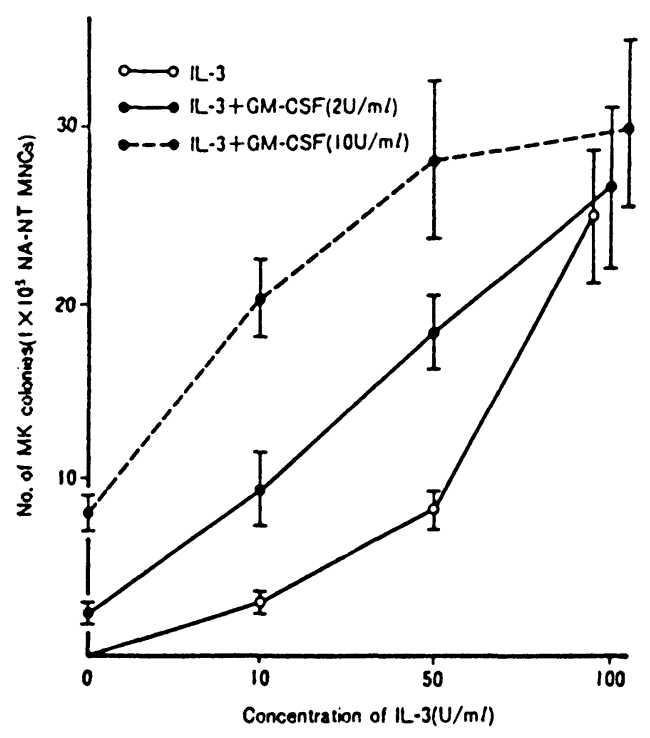

図 2 サイトカインと CFU-Meg. IL-3 と GMCSF を添加した時の人巨核球コロニー形成。 文献 (43) より

し, IL-3 と GM-CSF だけが巨核球コロニー 刺激因子として働いているとしている. IL-3 や GM-CSF が巨核芽球性細胞株の DNA 合 成を刺激したり cloning efficiency を高め

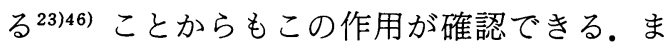
た IL-3 ${ }^{1144)} や \mathrm{GM}-\mathrm{CSF}^{10)}$ はコロニー形成を 刺激するが ploidy を増加させないとの成績も これらのサイトカインが巨核球増殖因子である が分化促進因子でないことを示しているのであ ろう。また IL-3 や GM-CSF の in vivo への 投与によっても血小板増多が観察できる ${ }^{47)}$. IL-3 は本来へルパー T 細胞由来のサイトカイ ンで $\mathrm{T}$ 細胞の初期の分化に関係する因子とし て見い出されたが現在は顆粒球, マクロフェー ジ，赤芽球そして肥満細胞などの血球を誘導す る multi-CSF, 赤芽球バースト形成刺激因子, 肥満細胞増殖因子，七スタミン産生細胞増殖因 子と同一のものと考えられ，多くの未分化な hemopoiotic cell の増殖を支持する因子である ことが判っている. IL-3 が巨核球コロニーの 刺激因子としでも働いているという最近の成績 は末分化な progenitor には lineage 特異の増 殖因子はなくIL-3 などの刺激によって偶然に 顆粒球，赤血球，巨核球へと分化していくとい
う Ogawa の血球分化に対する stochastic theory を支持していると考えてよい. では IL-3 や GM-CSF 以外に巨核球 progenitor に働く サイトカインはないのかというと興味あること に hypomegakaryocytic thrombocytopenia の患者血漿から分離された分子量 $46 \mathrm{KDa}$ の Meg-CSF に対する抗体は IL-3 や GM-CSF の巨核球コロニー形成に対する刺激効果を中和 しなかった ${ }^{48449)}$. また IL-3 や GM-CSF 抗体 は血小板減少患者血中の Meg-CSF を中和し ないなどの成績から IL-3 や GM-CSF 以外の 巨核球 progenitor の増殖因子の存在の可能性 が示唆されている.この本体の解明を期待した い.

エリスロポエチン（Epo）の巨核球 progenitor への効果については混乱がみられる.Sakaguchi ら ${ }^{50)}$ は Epo は巨核球コロニーへの刺 激作用があるとしており，またin vivo への Epo の大量投与によって血小板産生の元進を 示す所見が得られたとの報告51) もある。一方 Bruno $^{44)}$ は IL-1 $\alpha$ との併用でまた Dessypriss $\zeta^{51)}$ は PHA-LCM と併用すると巨核球増殖因 子として働くとしている。これらの成績の違い は用いた巨核球表面上の Epo 受容体の有無に よるのではなかろうか. 巨核球 progenitor の 一部に Epo の結合がみられる ${ }^{52) 53)}$ が，これら の細胞は Epo 添加によって増殖するのであろ う。しかし多くの巨核球には Epo 受容体はな いのではないか．事実腎性貧血治療のための Epo 投与では血小板増多がみられない.ただ 他のサイトカインとの併用で血小板增多という 臨床効果が得られるかもしれない.

Meg-CSF の in vivo での産生のフィードバ ック機構についてほとんど判っていない.ただ 血中への Meg-CSF 活性の出現は末梢血小板 数の増減ではなく ${ }^{54)}$ 骨髄中の巨核球数に応じ て増減することが骨髄移植患者での Meg-CSF の推移から観察されている ${ }^{55)}$. 反応性の造血は 一般的に T 細胞やマクロフェージが signal をキャッチしてサイトカインを産生して司って いると考えられているが，果して骨髄中の巨核 球減少が $\mathrm{T}$ 細胞やマクロフェージにサイトカ イン産生を指示することができるであろうか. 

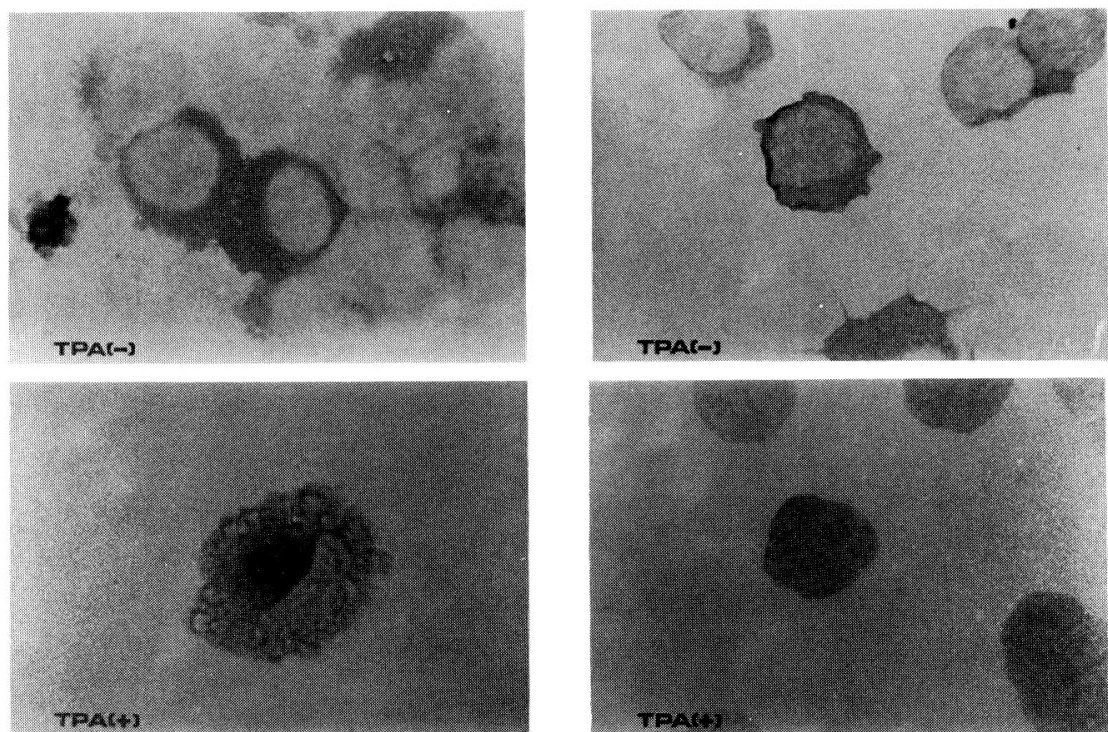

図 $3 \mathrm{CMK}$ と HL-60への TPA 添加による PKC の局在. $200 \mathrm{nmoles} / l \mathrm{TPA}$ を添 加後 PKC II 型抗体で ABC 染色を行った. 左側：CMK，右側：HL-60

私どもは骨髄中の巨核球 mass の低下が Meg-CSF (GM-CSF, IL-3 等) の増加を招来 するという臨床観察から，骨髄中で恒常的な造 血制御をしている stroma 細胞が骨髄での異 常を察知して Meg-CSF などのサイトカイン の産生を扝こない巨核球低下に対応しているの ではないかと考えているが，実際のところはど うなっているのであろうか.このフィードバッ ク機構の解明も期待される。

\section{Meg-potentiator}

Meg-potentiator は巨核球の ploidy 増加や 胞体の成熟を促し血小板を流血中に送り出す働 きを示すサイトカインということができる．血 小板減少患者の流血中にはトロンボポエチン （Tpo）と呼ばれる血小板産生を刺激する因子 があることが知られていたが現在もこの液性因 子の存在を容易に観察することができる ${ }^{57}$. Meg-potentiator は上卜胎児由来腎臓細胞株 (HEK) 上清から TSF ${ }^{56)}$ あるいは巨核球刺激 因子58) としてあるいはマクロフェージ細胞株 である P 388 D 1 培養上清59) からあるいは比 卜肺癌細胞株上清から精製分離が試みられてい るが Meg-CSF と同様完全に純化されたとの 報告はない，筆者たちの興味を惹いたのはヒト 肺癌細胞株上清が IL-3 や GM-CSF 添加後の 胞体の成熟のない巨核球の血小板特異抗原の発
現量を増加させたとの Long ら ${ }^{39)}$ の成績であ る.この上清中に生理的な Meg-potentiator が含まれるのではなかろうか，そして彼らはこ の胞体の成熟が tumor promotor であるフォ ルボールエステル（TPA）で再現できたとし ている。 TPA はよく知られているようにプロ テインカイネース C $(\mathrm{PKC})$ 介して細胞分化 を制御するので Meg-potentiator は巨核球の PKC 活性を刺激する液性因子と言い換えても よいのではなかろうか. 事実私どもは TPA 添加後 cytosolic な PKC が核の ploidy 増加 と膜の成熟を司る second messenger として働 いていることを示唆していると考えられる核と 膜への移動を示す所見を得た（図 3). Long ら はこの一連の仕事の中で IL-6 は巨核球分化を 司る作用はないと報告したが Ishibashi ら は IL-6 が巨核球の胞体の分化と多 ploidy 化 の作用があることを見い出し，さらに in vivo でも血小板増多作用があることを報告した ${ }^{61)}$ (図 4). IL-6 にはコロニー形成能はないが IL3 や GM-CSF 存在下で Meg-potentiator と して働くのではないかとして注目されてい る ${ }^{62)}$. ただ IL-6 は多彩な機能があり ${ }^{63)}$ ，その 中で急性期炎症蛋白の合成を促進することが知 られているが in vivo 投与の際も顕著な CRP の増加を招来する。再生不良性貧血患者で血中 

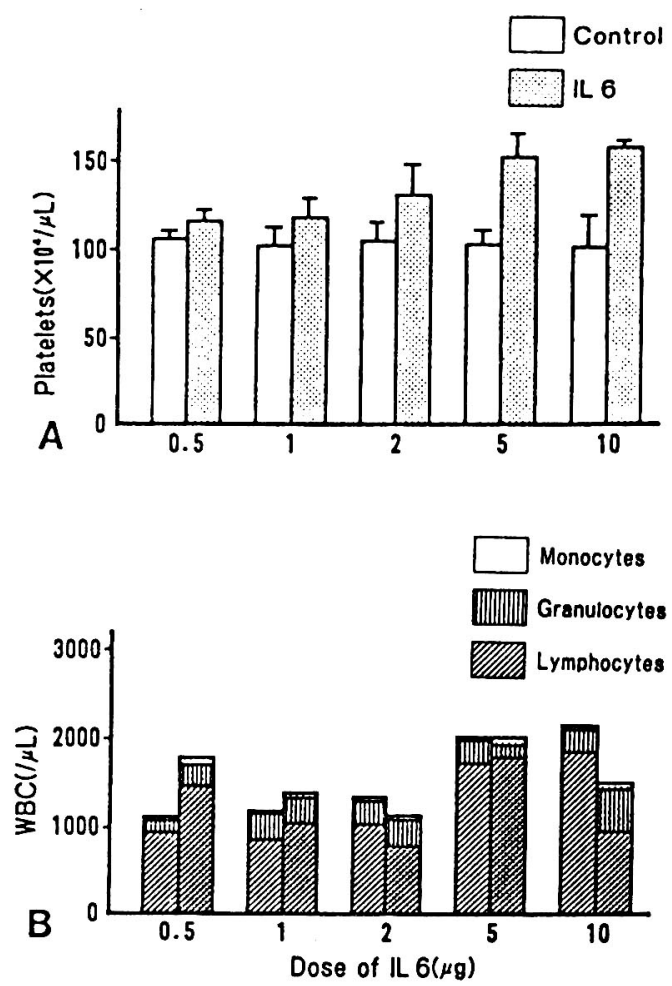

図 4 (A) Platelet and (B) differential cell counts in a dose response experiment of IL -6 in vivo in mice. Each dose of human rIL -6 indicated was administered in every 12 hours for five days. 文献（61）より

の Meg-potentiator が増加していると考えら れる際も臨床的に CRP の上昇が認められない ので, IL-6 以外の Meg-potentiator が存在す ることが十分考えられる。巨核球の ploidy を 上げる他のサイトカインとして Meg-CSF と して働き ploidy に影響しないと報告されてい る ${ }^{1145)}$ IL-3 に Ishibashi ら ${ }^{64)}$ は多 ploidy 化 の作用があると報告した。 また Epo にも同様 の作用があるとの成績も得られているので65)66) IL-3 や Epo も Meg-potentiator として働い ているかもしれない.したがって Megpotentiator は単一なサイトカインから成るの ではなく色々なサイトカインが微妙に絡み合っ て生体で機能している総体をいっていると考え た方が妥当であろう。

\section{その他}

巨核球分化は既知のサイトカインによって制 御されていることが明らかになった。すべての
サイトカインはネットワークを作って相互に影 響し合って造血に働いている3）ので巨核球分 化はすべてのサイトカインの制御を受けている といってもよいであうう，事実それに関する報 告も多い。また造血細胞に抑制的に働く TGF- $\beta^{67) 68)}$ やインターフェロンー $\alpha,-\beta^{69)}$ が巨 核球分化に影響するのは言うまでもないことで ある.ここでは巨核球は GM-CSFや IL6（佐藤武幸博士私信）mRNA をもっており， また巨核球 lineage の分化を特異的に抑制す ると考えられる血小板第 4 因子 $(\mathrm{PF}-4)^{70)}$ の

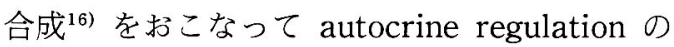
機構も精巧に備えていることを指摘しておきた い. また近年 IL-9 と名づけられるサイトカイ ンも巨核球分化を促進することが明らかになっ た ${ }^{71)}$.

\section{巨核球分化の過程}

巨核球 progenitor は GPIIb/IIIa を発現し ており, GPIIb/IIIa の発現は pluripotent 幹 細胞の同定にも役立つとの成績が得られていた が72)73), 最近のモノクローナル GPIIIa 抗体に よる cell sorting 後の細胞の巨核球コロニー形 成能の検索から巨核球 progenitor が GPIIIa をもっているとの見解は否定された ${ }^{74)}$.ただ巨 核球コロニーを作る単核球はCFU-E や CFU-C を作るので, 幹細胞の性質を兼衫備え ているということはできる。このもつとも未熟 な progenitor は CD 34 と HLA-DR などの MHC class II 抗原を発現しているのが特徵と される75) ので，もっとも未熟な巨核球は

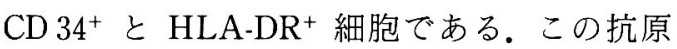
はIL-3 存在下で分化に従いCD $34^{-}$と HLA-DR ${ }^{+}$, そして CD $34^{-}$と HLA-DR- へ と変化する。この未熟な細胞は DNA を活発 に合成して分裂増殖するので in vitro ではコ ロニーとして観察することができる，形成され るコロニーは homogenious でなくもっとも未 熟な progenitor から，形成までに約 21 日間 と時間がかかり，コロニー当たり巨核球数が 30 個以上の BFU-Meg ${ }^{76)}$ ができる.コロニー 形成までに時間がかかり，細胞数が多いことは この progenitor がより未熟な段階の増殖能の 
表 3 増殖期の巨核球 progenitor

HLA-DR, CD 34 positive cells progenitor for BFU-Meg progenitor for CFU-Meg $\downarrow$ progenitor for LD-CFU-M

強い細胞であることを示す。通常認められるコ ロニーは形成までに約 12 日間かかり，コロニ 一当たり巨核球 3 個以上認める CFU-Meg で ある.より分化した progenitor からのコロニ ーである。さらに分化した progenitor から LD-CFU-Meg と呼ばれる77) コロニーが形成さ れる，通常より低い比重の progenitor に由来 し，コロニー形成が弱く，コロニー中の巨核球 は高い ploidy を持っているのが特徵とされ る.まだヒトでは確認されていない.私どもは ここまでの細胞を増殖の活発な early stage の 巨核球と考えている（表 3 )。この増殖期を過ぎ ると巨核球は分裂する細胞から巨核球に特異的 な endomitosis と呼ばれる分裂しないで核の DNA 合成だけを行い $4 \mathrm{~N}, 8 \mathrm{~N}, 16 \mathrm{~N}$ そして $32 \mathrm{~N}$ と ploidy の増加を示す巨核球へと分化 していく．私どもは ploidy の上昇がみられる 巨核球を分化期の巨核球と考えている（表 4).

\section{分化期の巨核球}

分化を開始した巨核球は ploidy の上昇と同

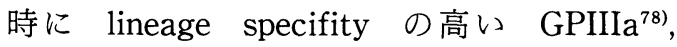
GPIIb/IIIa ${ }^{79)}$ などの膜抗原を発現する。この 細胞は transitional megakaryocyte ${ }^{80)}$ として 正常の骨髄細胞の中にも確認することができ る。単芽球様の形態を示すがコロニー形成能は なく血小板特異抗原やPPO 活性が陽性で ploidy は $4 \mathrm{~N}$ 以上である5). endomitosis の 開始は巨核球の分化を考える意味で大切な段階 なのでそれに関する興味ある成績を紹介してお きたい. Arriaga ら ${ }^{81)}$ は放射線照射後のイヌ 血清を用いて mitosis と endomitosis に及ぼ す効果を観察したところ，低濃度の血清は mitosis と endomitosis を増加させ, 高濃度の 血清は mitosis だけを上昇させることを見い 出した。この所見は強い刺激に対してまず
表 4 分化期の巨核球

$$
\begin{gathered}
\text { transitional megakaryocytes } \\
\downarrow \\
\text { ploidy の増加 } \\
\text { 膜マーカーの出現 } \\
\downarrow \\
\text { cytoplasmic protein の出現 } \\
\text { PF-4 } \\
\text { thrombospondin } \\
\downarrow \\
\text { dense membrane system } \\
\alpha \text {-granules }
\end{gathered}
$$

mitosis で反応し，一段落すると mitosis から endomitosis への反応に移行していくことを示 しており，巨核球の mitosis と endomitosis は外からの刺激に応じいつもリンクしながら生 体内で制御を受けているとした。 endomitosis の活発な巨核球は大型化していくのが特徵であ る. 一般的に大型の巨核球は ploidy が高い. しかし Ebbe ら ${ }^{82)}$ は血小板減少マウスの巨核 球の size と ploidy を検討し, 血小板減少時 は ploidy の上昇より巨核球の大型化の方が顕 著であることを見い出し， ploidy の上昇と size の大型化は異なった機序による制御を受 けているとした．臨床的にもITP において ploidy に比較して巨核球の大型化の方が目立 つとの Nomura ら ${ }^{83)}$ の観察がある。巨核球 の胞体の増大は膜マーカーの増強と cytoplasmic 蛋白の合成がはじまったことを示唆してい る. Vinci ら ${ }^{84)}$ は CFU-Meg を用いて膜マー カーとして GP そして cytoplasmic 蛋白のマ ーカーとして PF-4 や von Willebrand (VW) 因子の出現の経時的変化を検討して, いずれの 蛋白もコロニー形成を開始した約 5 日後という 早期にほぼ同時に出現してくるという所見を得 た。しかし巨核芽球性白血病の phenotype の 検索はこれを支持しない ${ }^{85) 86}$. 多くの白血病細 胞は GPIIb/IIIa の発現が強いのに比較して $\mathrm{GPIb}$ やPF-4の発現がないのが特徴であ る ${ }^{87)}$.これは分化傾向を有する細胞だけが PF-4 の発現を認める ${ }^{88)}$ という所見からも確 認されている。したがって胞体の分化は膜マー カーの出現，ひき続いて cytoplasmic 蛋白の 出現を伴うと考えるのが妥当であろう．図 5 , 


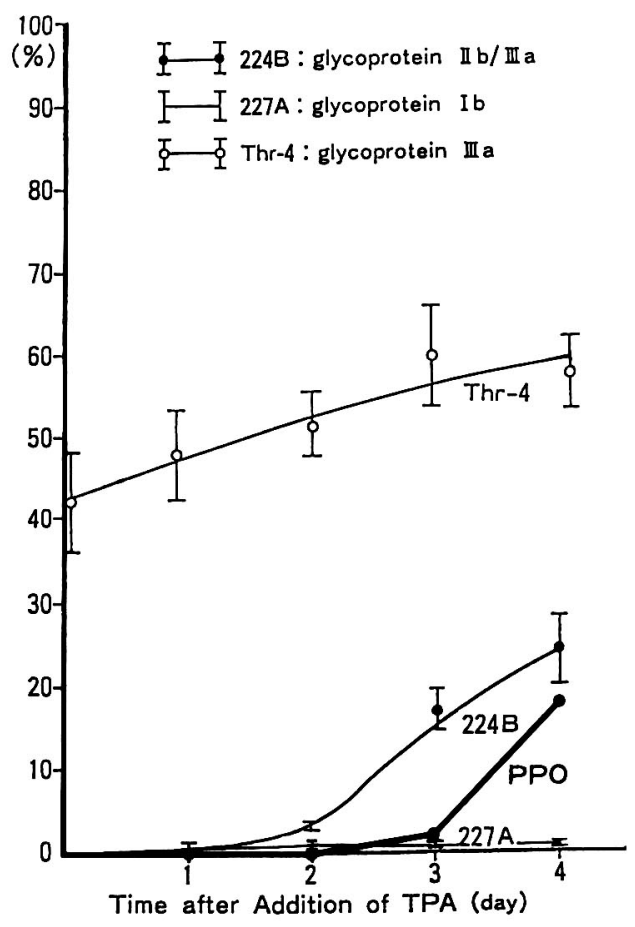

囯 $5 \mathrm{~K} 562$ に TPA $10 \mathrm{nmoles} / l$ 添加 4 日後ま での表現型の変化. 文献（78）より
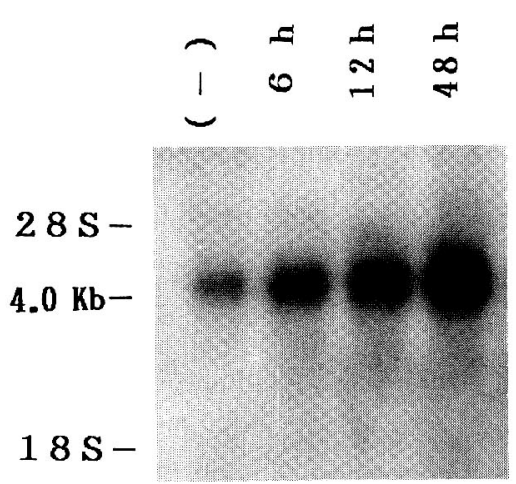

图 $7 \mathrm{CMK}$ 細胞に TPA $10 \mathrm{nmoles} / l$ 添加後の GPIIb mRNA $\odot$ Northern blot 像

6 に K 562 の TPA による phenotype の経時 的変化を示す。膜マーカーから cytoplasmic 蛋白のトロンボスポンジンの合成される時期に 違いがあることがよく理解できる．ただ抗原量 の変化だけで発現の時期を論じることには問題 があるかもしれない，産生される抗原量や測定 する感度によって容易に間違った解釈がなされ る可能性がある. 抗原量は遺伝子発現の後増減

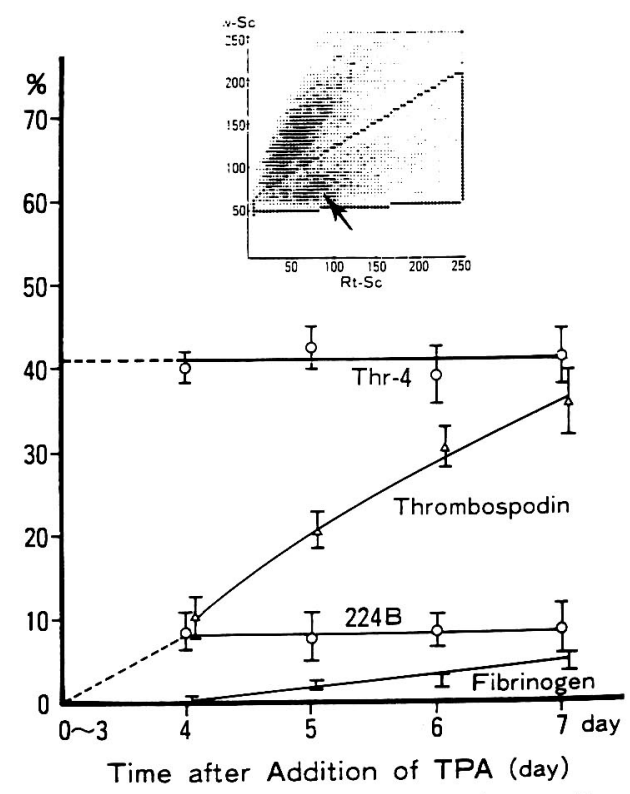

図 $6 \mathrm{~K} 562$ に $10 \mathrm{nmoles} / l \mathrm{TPA}$ 添加 4 7 後の 表現型の変化. 文献 (78) より

Thr-4 : GPIIIa, 224 B : GPIIb/IIIa

を示すので, 発現の時期は遺伝子レベルでの検 索によって結論づけるべきであろう。図 7 に TPA 添加後の CMK の GPIIb mRNA の動き を示す。この遺伝子の増強は細胞表面の GPIIb 量の変化より遙かに早い時期に挙動し ている.

ひき続き巨核球は $\alpha$-顆粒の構築そして dense membrane system の成熟へと分化して 血小板産生を行う ${ }^{20)}$.

\section{まとめ}

巨核球分化の研究は血小板確保という臨床サ イドの要請に応えるためにも極めて大切であ る. 現時点での巨核球の分化に関する知見をま とめてみた. 今回は枚数の制限で記述しなかっ たが，巨核球の分化の研究は血小板特異蛋白の 合成経路の解明や血小板の刺激応答系の伝達機 構に有用な情報 ${ }^{89990)}$ を与えてくれる。

\section{文献}

1) Vainchenker, W., Bouget, J., Guichard, J., Breton-Gorius, J. : Megakaryocyte colony formation from human bone marrow precursors. 
Blood, 54 : 940 945, 1979.

2) Vainchenker, W., Deschamps, J. F., Bastin, J. M., Guichard, J., Titenx, M., Breton-Gorius, J., McMichael, J.: Two monoclonal antiplatelet antibodies as markers of human megakaryocyte maturation: Immunofluorescent staining and platelet peroxidase detection in megakaryocyte colonies and in in vivo cells from normal and leukemic patients. Blood, 59 : 514 521, 1982.

3) Sieff, C. A.: Hematopoietic growth factors. J. Clin. Invest., $79:$ 1549 1557, 1987.

4）血小板1989-血小板産生- : 青木延雄, 蔵本淳, 日高弘 義, 山崎博男, 大熊稔 編, 科学評論社, 東京 1989.

5) Hoffman, R. : Regulation of megakaryocytopoiesis. Blood, $74: 1196 \sim 1212,1989$.

6) Kimura, H., Burnstein, S. A., Thorning, D., Powell, J. S., Harker, L. A., Fialkow, P. J., Adamson, J. W. Human megakaryocytic progenitors (CFU-M) assayed in methylcellulose: Physical characteristics and requirements for growth. J. Cell Physiol., 118 : 87 96, 1984.

7) Kuriya, S., Kwak, J., Tajika, K., Minoda, Y., Nomura, T., Murphy, Jr. M. J. : Cloning of murine megakaryocyte progenitor cells in a fibrin clot culture system. Exp. Hematol., 15 : 896 901, 1987.

8) Teramura, M., Katahira, J., Hoshino, S., Motoji T., Oshimi K., Mizoguchi, H. : Clonal growth of human megakaryocyte progenitors in serum-free cultures : Effect of recombinant human interleukin 3. Exp. Hematol., 16 : 843 848, 1988.

9) Bruno, E., Briddell, R., Hoffman, R. : Effect of recombinant and purified hematopoietic growth factors on human megakaryocyte colony formation. Exp. Hematol., $16: 371 \sim 377,1988$.

10) Mazur, E. M., Cohen, J. L., Wong, G. G., Clark, S. C. : Modest stimulatory effect of recombinant human GM-CSF on colony growth from peripheral blood human megakaryocyte progenitor cells. Exp. Hematol., 15 : 1128 1133, 1987.

11) Mazur, E. M., Cohen, J. L., Bogart, L., Mufson, R. A., Gesner, T. G., Yang, Y. C., Clark, S. C. : Recombinant gibbon interleukin-3 stimulates megakaryocyte colony growth in vitro from human peripheral blood progenitor cells. J. Cell.
Physiol., 136 : 439 446, 1988 .

12) Long, M. W., Gragowski, L. L., Hoffner, C. H., Boxer, L. A.: Phorbol diesters stimulate the development of an early murine progenitor cell. The burst-forming unit-megakaryocyte. J. Clin. Invest., 76 : 431 438, 1985.

13) Levine, R. F., Fedorko, M. E. : Isolation of intact megakaryocytes from guinea pig femoral marrow. Successful harvest made possible with inhibitors of platelet aggregation:Enrichment achieved with a two step separation technique. J. Cell Biol., 69 : 159 172, 1976.

14) Ishibashi T., Ruggeri Z. M., Harker, L. A., Burnstein, S. A.: Separation of human megakaryocytes by state of differentiation on continuous gradients of Percoll : Size and ploidy analysis of cells identified by monoclonal antibody to glycoprotein IIb/IIIa. Blood, 67 : 1286 1292, 1986.

15) Saigo, K., Ryo, R., Nakaya, Y., Yamaguchi N. : Isolation of megakaryocytes by a combination of density gradient centrifugation and velocity sedimentation, and centrifugal elutriation. Kobe J. Med. Sci., 31 : 251 261, 1985.

16) Ryo R., Nakeff, A., Huang, S. S., Ginsberg, M., Deuel, T.: New systhesis of a platelet-specific protein: Platelet factor 4 synthesis in a megakaryocyte-enriched rabbit bone marrow culture system. J. Cell Biol., o396 : 515 520, 1983.

17) Berkow, R. L., Straneva, J. E., Bruno, E., Beyer, G. S., Burgess, J. S., Hoffman, R. : Isolation of human megakaryocytes by density centrifugation and counterflow centrifugal elutriation. J. Lab. Clin. Med., 103 : 811 818, 1984.

18) Straneva, J. E., Goheen, M. P., Hui, S. L., Bruno, E., Hoffman, R. : Terminal Cytoplasmic maturation of human megakaryocytes in vitro. Exp. Hematol., 14 : 919 929, 1986.

19) Tomer, A., Harker, L. A., Burnstein, S. A. : Purification of human megakaryocytes by fluorescence-activated cell sorting. Blood, 70 : 1735 1742, 1987

20) Tabilio, A. : Myeloid and megakaryocytic properties of K-562 cell lines. Cancer Res., $43: 4569$ $\sim 4574,1983$

21) Tabilio, A., Pelicci, P., Vinci, G. : Expression of 
platelet membrane glycoproteins by a human erythroleukemic cell line (HEL). ENMBO J., 3 : 453 459, 1984.

22) Sato, T., Fuse, A., Eguchi M., Hayashi, Y., Ryo, R., Adachi, M., Kishimoto, Y., Teramura, M., Mizoguchi H., Shima, Y., Komori, I., Sunami, S., Okimoto, Y., Nakajima, J. : Establishment of a human leukemic cell line (CMK) with megakaryocytic characteristics from a Down's syndrome patient with acute magakaryoblastic leukemia. Brit. J. Haematol., 72 : 184 190, 1989.

23) Avanzi, G. C., Lista, P., Giovinozzo, B., Miniero, R., Soglio, G., Bennetton, G., Coda, R., Gattoretti, G., Pegoravo, L.: Selective growth response to IL-3 of a human leukaemic cell line with megakaryoblastic features. Brit. J. Haematol., 69 : 359 〜366, 1988.

24) Greenberg, S. M., Rosenthal, D. S., Greenley, T. A., Tantravahi R., Hondin, R. I. : Characterization of a new megakaryocytic cell line:The Dami cell. Blood, 72 : 1968 1977, 1988.

25) Ogura, M., Morishima, Y., Okumura, M., Hotta, T., Takamoto, S., Ohno, R., Hirabayashi, N., Nagura, H., Saito, H.: Functional and morphological differentiation induction of a human megakaryoblastic leukemia cell line (MEG-01s) by phorbol diesters. Blood, 72: 49 60, 1988.

26) Sledge, G. W., Glant, M., Jansen, J., Heerema, N. A., Roth, B. J., Goheen, M., Hoffman, R. : Establishment in long term culture of megakaryocytic leukemia cells (EST-IU) from the marrow of a patient with leukemia and a mediastinal germ cell neoplasia. Cancer Res., 46 : 2155 2159, 1986.

27) Tange, T., Nakahara, K., Mitani, K., Yamasaki, I., Yasuda, H., Tanaka, F., Mizuguchi, M., Oda, H., Yatani Y., Takanashi R., Fujioka, S., Yamaguchi, K., Urano Y.: Establishment of a human megakaryocytic cell line ( $T$-33) from chronic myelogenous leukemia in megakaryoblastic crisis. Cancer Res., 48:6137 6144, 1988.

28) Levin, J., Levin, F. C., Hull III, D. F., Penington, D. G.: The effects of thrombopoietin on megakaryocyte-CFC, megakaryocytes, and thrombopoiesis: With studies of ploidy and platelet size. Blood, 60: 989 998, 1982.
29) McDonald, T. P., Cottrell, M. B., Clist, R. E., Cullen, W. C., Lin, F. K. : High doses of recombinant erythropoietin stimulate platelet production in mice. Exp.Hematol., $15: 719 \sim 721,1987$.

30) Kawada, K., Kuriya, S, Dan, K., Sakamaki, H., Hamaguchi H., Nomura, T.: Thrombopoietic activity of serum fractions in mouse and man. Acta Haematol. Jpn., 42:65 71, 1979.

31) Hoffman, R., Mazur, E., Bruno, E., Floyd, V.: Assay of activity in the serum of patients with disorders of thrombopoiesis that stimulates formation of megakaryocytic colonies. New Engl. J. Med., 305 : 533 538, 1981.

32) Williams, N., Eger, R. R., Jackson, H. M., Nelson, D. J. : Two-factor requirement for murine megakaryocyte colony formation. J. Cell Physiol., 110 : 101 104, 1982.

33) Hoffamn, R., Yang, H. H., Bruno, E., Straneva, J. E. : Purification and partial characterization of a megakaryocyte colony-stimulating factor from human plasma. J. Clin. Invest., 75 : 1174 1182, 1985.

34) Kawakita, M., Ogawa, M., Goldwasser, E., Miyake, T.: Characterization of human megakaryocyte colony-stimulating factor in the urinary extracts from patients with aplastic anemia and idiopathic thrombocytopenic purpura. Blood, 61 : 556 560, 1983.

35) Ogata, K., Kuriya, S., Dan, K., Nomura, T. : Partial purification of human urinary megakaryocyte colony-stimulating factor. Exp. Cell Biol., $57: 19 \sim 26,1989$

36) Williams, N., Sparrow, R., Gill, K., Yasmeen, D., McNiece, I.: Murine megakaryocyte colony stimulating factor: Its relationship to interleukin 3. Leuk. Res., $12: 1487 \sim 1496,1985$.

37) Quesenberry P. J., Ihle, J. N., McGrath E. : The effect of interleukin 3 and GM-CSA-2 on megakaryocyte and myeloid clonal colony formation. Blood, 65 : 214 217, 1985.

38) Lu, L., Briddlell, R. A., Graham, C. D., Brandt, J. E., Bruno, E., Hoffman, R.: Effect of recombinant and purified human haematopoietic growth factors on in vitro colony formation by enriched populations of human megakaryocyte 
progenitor cells. Brit. J. Haematol., 70 : 149 156, 1988.

39) Long, M. W., Hutchinson, R. J., Gragowski, L. L., Heffner, C. H., Emerson S. G. : Synergistic regulation of human megakaryocyte development. J. Clin. Invest., $82: 1779 \sim 1786,1988$.

40) Robinson B. E., McGrath, H. E., Quesenberry P J. : Recombinant murin granulocyte macrophage colony-stimulating factor has megakaryocyte colony-stimulating activity and augments megakaryocyte colony stimulatin by interleukin 3 . J. Clin. Invest., 79 : 1648 1652, 1987.

41) McNiece, I. K., McGrath, H. E., Quesenberry, P J. : Granulocyte colony-stimulating factor augments in vitro megakaryocyte colony formation by interleukin 3. Exp. Hemato., 16:807 810, 1988.

42) Emerson J. G., Yang, U. C., Clark, S. C., Long, M. W. : Human recombinant granulocytemacrophage colony stimulating factor and interleukin 3 have overlapping but dictinct hematopoietic activities. J. Clin.Invest., 82 : 1282 〜287, 1988.

43）寺村正尚, 溝口秀昭: 各種造血因子の巨核球産生に 対する影響-無血清ヒト巨核球]コロニー培養によ る検討 (青木延雄, 蔵本淳, 日高弘義, 山崎博男, 大熊 稔 編: 血小板1989-血小板産生-), 科学評論社, 東 京, 1989, p68〜 79.

44) Bruno, E., Miller, M. E., Hoffman, R. : Interacting cytokines regulate in vitro human megakaryocytopoiesis. Blood, 73:671 677, 1989.

45) Segal, G. M., Stneve, T., Adamson, J. W. : Analysis of murin megakaryocyte colony size and ploidy : Effects of interleukin-3. J. Cell Physiol., 137 : 537 544, 1988.

46) Komatsu, N., Suda, T., Moroi, M., Tokuyama, N., Sakata, Y., Okada, M., Nishida, T., Hirai, Y., Sato, T., Fuse, A., Miura, Y.: Growth and differentiation of a human megakaryoblastic cell line, CMK. Blood, 74 : 42 48, 1989.

47) Donahue, R. E., Seehra, J., Metzger, M., Lefebvre, D., Rock, B., Carbone, $S_{\Downarrow}$ Nathan, D. G., Granic, M., Sehgal, P, K., Laston, D., LaVallie, E., McCoy, J., Schendel, P. F., Norton, C., Turner, K., Yang, Y., Clark, S. B. : Human IL-3 and
GM-CSF act synergistically in stimulating hematopoiesis in primates. Science, 241:1820 1822, 1988.

48) Straneva, J. E., Yang, H. H., Hui, S. L., Bruno, E., Hoffman, R. : Effects of megakaryocyte colonystimulating factor on terminal cytoplasmic maturation of human megakaryocytes. Exp. Hematol., 15 : 657 663, 1987.

49) Straneva, J. E., Briddlell, R. A., McDonald, T. P., Yang H. H., Hoffamn, R. : Thrombocytopoiesis stimulating factor (TSF) in aplastic anemia serum accelerates cytoplasmic maturation of human megakaryocytes. Exp. Hematol., 16 : 217 225, 1988.

50) Sakaguchi, M, Kawakita, M., Matsushita, J., Shibuya, K., Koishihara Y., Takatsuki, K. : Human erythropoietin stimulates murine megakaryopoiesis in serum-free culture. Exp. Hematol., 15 : 1028 1034, 1987.

51) Dessypris, E. N., Gleaton, J. H., Armstrong, O. L. : Effect of human recombinant erythropoietin on human marrow megakaryocyte colony formation in vitro. Brit. J. Haematol., 65:265 269, 1987.

52) Fraser, J. K., Lin, F., Berridge, M. V. : Expression of high affinity receptors for erythropoietin on human erythroleukemic cell line, HEL. Exp. Hematol., 16 : 836 842, 1988.

53) Fraser, J. K., Tan, A. S., Lin, F., Berridge, M. B. : Expression of specific high-affinity binding sites for erythropoietin on rat and mouse megakaryocytes. Exp. Hematol., $17: 10 \sim 16,1989$.

54) Miura, M., Jackson, C. W., Steword, S. A. : Increase in circulating megakaryocyte growthpromoting activity (Meg-GPA) following sublethal irradiation is not related to decreased platelets. Exp. Hematol., 16 : 139 144, 1988.

55) Yamasaki, K., Solberg, L. A., Jamal, N., Lockwood, G., Tritchler, D, Curtis, J. E., Minden, M. M., Mann, K. G., Messner, H. A. : Hemopoietic colony growth-promoting activities in the plasma of bone marrow transplant recipients. J. Clin. Invest. 82 : 255 261, 1988.

56) McDonald, T. P. : Thrombopoietin: Its biology, purification and characterization. Exp. 
Hematol., 16 : 201 205, 1988.

57) Straneva, J. E., Briddell, R. A., Hui, S. L., Hoffman, R.:Serum from patients with various thrombopoietic disorders alters terminal cytoplasmic maturation of human megakaryocytes in vitro. Eur. J. Haemat. 42: 293 297, 1989.

58) Tayrien, G., Rosenberg, R. D. : Purification and properties of a megakaryocyte stimulatory factor present both in the serum-free conditioned medium of human emryonic kidney cells and in thrombocytopenic plasma. J. Biol. Chem. 262 : 3262 3268, 1987.

59) Sparrow, R. L., Swee-Huat, D., Williams, W.: Haemopoietic growth factors stimulating murine megakaryocytopoiesis: Interleukin-3 is immunologically distinct from megakaryocytepotentiator. Leukemia Res. 11 : 31 36, 1987.

60) Ishibashi, T., Kimura, H., Uchida, T., Kariyone, S., Friese, P., Burnstein, S. A. : Human interleukin 6 is a direct promoter of maturation of megakaryocytes in vitro. Proc. Natl. Acad. Sci. USA 86 : 5953 5957, 1989.

61) Ishibashi, T., Kimura H., Uchida, T., Kariyone, S., Hirano, T., Kishimoto, T., Takatsuki, F., Akiyama, Y.: Interleukin-6 is a potent thrombopoietic factor in vitro in mice. Blood $74: 1241$ 〜244, 1989.

62) Lotem, J., Shabo, Y., Sachs, L. : Regulation of megakaryocyte development by interleukin- 6 . Blood 74 : 1545 1551, 1989.

63) Kishimoto, T.: The biology of interleukin- 6 . Blood 74 : 1 10, 1989.

64) Ishibashi T., Burnstein, S. A. : Interleukin 3 promotes the differentiation of isolated single megakaryocytes Blood. 67 : 1512 1514, 1986.

65) Ishibashi T., Kosiol, J. A., Burnstein, S. A. : Human recombinant erythropoietin promotes differentiation of murine megakaryocytes in vitro. J. Clin. Invest. 79 : 286 289, 1987.

66) Nagasawa, T., Neichi T., Satoh, K., Nakazawa, M., Abe, T. : in vitro regulatory mechanisms for cytoplasmic maturation of murine megakaryocytes derived from colony-forming units megakaryocyte (CFU-M). Exp. Hematol. 16:667 $\sim 673,1988$.
67) Ishibashi, T., Miller, S. L., Burnstein, S. A. : Type trans-forming growth factor is a potent inhibitor of murine megakaryocytopoiesis in vitro. Blood. 69 : 1737 1741, 1987.

68) Alitalo, R., Mäkelä, T. P., Koskinen, P., Andersson, L. C., Alitalo, K. : Enhanced expression of transforming growth factor $\beta$ during megakaryoblastic differentiation of K562 leukemia cells. Blood. 71 : 899 906, 1988.

69) Gauser, A., Carlo-Stella, C., Greher, J., Volkers, B., Hoelzer, D. : Effect of recombinant interferons alpha and gamma on human bone marrowderived megakaryocytic progenitor cells. Blood. 70 : 1173 1179, 1987

70) Gewirtz, A. M., Galabretta, B., Rucinski, B., Niewiarowski, S., Xu, W. T.: Inhibition of human megakaryocytopoiesis in vitro by platelet factor $4(\mathrm{PF} 4)$ and a synthetic $\mathrm{COOH}$-terminal PF4 peptide. J. Clin. Invest. 83 : 1477 1486, 1989.

71) Yang, Y., Ricciardi, S., Ciarletta, A., Calvetti J., Kelleher, K., Clark, S. C. : Expression cloning of a cDNA encoding a novel human hematopoietic growth factor: Human homologue of murine T-cell growth factor P40. Blood. $74: 1880 \sim 1884$, 1989.

72) Berridge, M. V., Ralph, S. J., Tan, A. S. : Celllineage are associated with the platelet $\mathrm{II}_{b}-\mathrm{III}_{\mathrm{a}}$ glycoprotein complex. Blood. 66 : 76 85, 1985.

73) Fraser, J. K., Leahy, M. F., Berridge, M. V.: Expression of antigens of the platelet glycoprotein $\mathrm{II}_{\mathrm{b}} / \mathrm{III}_{\mathrm{a}}$ complex on hman hematopoietic stem cells. Blood $68: 762 \sim 769,1986$.

74) Kanz, L., Mielke, R., Fauser, A. A. : Analysis of human hemopoietic progenitor cells for the expression of glycoprotein $\mathrm{III}_{\mathrm{a}}$. Exp. Hematol. $16: 741 \sim 747,1988$.

75) Caux, C., Favre, C., Saeland, S., Dubert, V., Mannoni, P., Durand, I., Aubry, J., de Vries, J. E. : Sequential loss of $\mathrm{CD} 34$ and class II $\mathrm{MHC}$ antigens on purified cord blood hematopoietic progenitors cultured with IL-3 : Characterization of CD34-, HLA-DR ${ }^{+}$cells. Blood. $74: 1287 \sim 1294$, 1989.

76) Briddell, R. A., Brandt, J. E., Straneva, J. E., Srour, E. F., Hoffman, R. : Characterization of 
the human burst-forming unit-megakaryocyte. Blood 74 : 145 151, 1989.

77) Chatelain, C., Bast, M. D., Symann, M. : Identification of a light density murine megakaryocyte progenitor (LD-CFU-M). Blood. 72 : 1187 1192, 1988.

78) Adachi M., Ryo, R., Yoshida, A., Yoneda, N., Tatsumi E., Yamaguchi N., Kishimoto, Y.: Kinetic study of platelet glycoproteins and PPO activity in TPA-induced K562 cells. Acta. Haematol. Jpn. 51 : 1069 1079, 1988.

79) Breton-Gorius, J. and Vainchenker, W. : Expression of platelet proteins during the in vitro and in vivo differentiation of megakaryocytes and morphological aspects of their maturation. Sem. Hematol. 23 : 43 67, 1986.

80) Rabellino E. M., Levene, R. B., Leung, L. L. K., Nachman, R. L. : Human megakaryocytes. II. Expression of platelet proteins in early marrow megakaryocytes. J. Exp. Med. 154 : 88 100, 1981.

81) Arriaga, M., South, K., Cohen, J. L., Mazur, E. M. : Interrelationship between mitosis and endomitosis in cultures of human megakaryocyte progenitor. Blood. 69 : 486 492, 1987.

82) Ebbe, S., Yee, T., Carpentor, D., Phalen, E.: Megacaryocytes increase in size within ploidy groups in response to the stimulus of thrombocytopenia. Exp. Hematol. $16: 55 \sim 61,1988$.

83) Nomura, T., Kuriya, S., Dan, K. : Characteristics of megakaryocytes in relation to platelet production in idiopathic thrombocytopenic purpura. Acta. Haematol. Jpn. 46 : 1541 1546, 1983.
84) Vinci, G., Tabilio, A., Deschamps, J. F., van Haeke, D, Henri, A., Guichard, J., Tetteroo, P., Lansdorp P. M., Hercend, T., Vainchenker, W, Breton-Gorius, J.: Immunological study of in vitro maturation of human megakaryocytes. Brit. J. Haematol. 56 : 589 605, 1984.

85) Koike, T.: Megakaryoblastic leukemia: The Characterization and identification of megakaryoblasts. Blood. $64: 683 \sim 692,1986$.

86）寮隆吉, 吉田明憲, 山口延男 : 巨核芽球性細胞株と巨 核芽球性白血病. 臨床病理. 83: 514 523, 1990.

87) Adachi, M., Ryo, R., Yoshida, A., Yamaguchi, N., Izumi, Y.: Refractory anemia terminating in a acute megakaryoblastic leukemia (M7). Acta. Haematol. 81 : 104 108, 1989.

88) Ryo, R., Adachi, M., Sugano, W., Yasunaga, M., Yoshida, A., Jikai, J., Saigo, K., Yamaguchi, H., Akita, H., Yokoyama, M., Konaka, Y., Poncz, M. : Platelet factor $4 \mathrm{mRNA}$ in cells from a patient with megakaryoblastic crisis of chronic myelogenous leukemia. Cancer 1990 (in press).

89) Adachi, M., Ryo, R., Yoshida, A., Teshigawara, K., Yamaguchi, N., Hoshijima, M., Takai, Y., Sato, T. : Elevation of intracellular calcium ion by prostaglandin $E_{1}$ and its inhibition by protein kinase $\mathrm{C}$ in a human megakaryocyte leukemia cell line. Cancer Res. 49 : 3805 3808, 1989.

90) Ryo, R., Yoshida, A., Adachi, M., Sugano, W., Yamaguchi, N., Sato, T. : Cytosolic $\mathrm{Ca}^{2+}$ mobilization and thromboxane synthesis in a human megakaryocytic leukemia cell. Exp. Hematol. 1990 (in press). 